\title{
Fiction and Newsreel Documentary in Godard's Cinema
}

\author{
Pietro GIOVANNOLI
}

\section{DOCUMENTARY AND FICTION. An EMBLematic LEGEND}

There is a legend that Godard would have been one of the special guests in the live broadcast of the Moon landing on the First National French channel (ORTF1) and that he would have pretended that the world-wide televised images were just a really convincing fake ("ce direct est un faux"; "ce qu'on voit c'est un film monsieur"). ${ }^{1}$ These phrases, which presumably were never uttered by Godard—who, in his most violent Marxist-Maoist period, would have been a very unlikely guest for such an event-are nevertheless emblematic of the close relationship that Godard's cinema maintains with both fiction and documentary or-more specifically to the subject of our volume- to newsreel cinema. A dozen years later the successful mission of the Apollo 11, Godard, guest of Jean-Luis Burgat at the live tap-

1 Guillas 2009, Hansen-Løve 2010. Following Karel 2003: 5, Godard would have expressed his doubts in the "journal de TF1". - In an interview with A. Fleischer (director of MORCEAUX DE CONVERSATIONS AVEC JEAN-LUC GODARD), when asked if "Le commentaire de Jean-Luc Godard sur la non-vérité de l'homme sur la Lune est-il confirmé?" Fleischer answered "Godard est capable de toutes sortes de provocations, y compris sur des thèmes plus graves. On a parlé même d'une certaine forme de négationnisme chez lui. Dans ce cas, il pourrait en effet nier l'homme sur la Lune, puisque cet homme est américain" (Fleischer 2009). 
ing of the 7 SUR 7 (a daily TV show on air between 7 and 8 PM), commenting on some footage of the third part of the weekly news that presented images from European space missions, provocatively asked: "Pourquoi c'est complètement flou toutes ces images, ...toujours?" When Burgat candidly answered "Parce que elles viennent de très loin", Godard sceptically objected: "Ouais mais avec la technique [...] Moi je pense que c'est truqué, c'est des maquettes faites par Lucas... ça c'est pas vrai". ${ }^{2}$

More than fifteen years earlier, in a 1967 interview shot by Jean-Paul Savignac for the first national channel, Godard affirmed that his job, if he had lived in the future, would have been "Cameraman sur la lune, faire le journal de bord d'une fusée, la télévision d'une province, que cette province soit Perpignan ou Vénus" (CHRONIQUES DE FRANCE). In the same year, also evoking journalism and the Moon, Godard had already reflected about fiction and cinematic mimesis, making Jean-Pierre Léaud say in LA CHINOISE [1967] ${ }^{3}$ - reversing the famous equation by Truffaut - that Lumière was a painter, the last impressionist, while Méliès was the real documentary-maker:

Guillaume: Camarades et amis, aujourd'hui je vais vous parler des actualités. Audience: On sait ce que c'est. On en voit au cinéma.

G: Oui mais justement, il y a une idée fausse qui circule à propos des actualités au cinéma. On dit que c'est Lumière qui a inventé les actualités, ou que lui faisait de documentaire, alors qu' à la même époque il y avait un autre type, s'appelait Méliès, dont tout le monde dit que lui faisait de la fiction, donc qui était un rêveur qui filmait des fantasmagories. Et moi je pense justement que c'est le contraire [...] et il y a un film de M. Henri Langlois, directeur de la Cinémathèque, sur Lumière, et ce film prouve que Lumière était un peintre. C'est à dire qu'il filmait exactement les mêmes choses que peignaient les peintres contemporains de son époque... des gens come Pissarro, Manet ou Renoir, [...] il filmait des gares, il filmait des jardins publics, il

2 Some footage from this broadcast is present in Michel Royer's 1999 documentary GODARD À LA TÉLÉ. "Lucas" is probably George Lucas, creator of the space opera franchise STAR WARS. In this case Godard offers an alternative director to the moon hoax conspiracy theories according to which the fake moon landing was shot by Stanley Kubrick (see for example OPÉRATION LUNE).

3 Léaud's speech, as we can read on the blackboard that stands behind him, is called "Problèmes d'information: Pour une TV républicaine". 
filmait des sorties d'usines, il filmait des gens qui jouent aux cartes, il filmait des tramways.

A: Il était un des derniers grands peintres impressionnistes de l'époque ?

G: Oui, oui, exactement c'était un contemporain de Proust, quoi. [...] ... Méliès, Méliès qu'est-ce qu'il faisait par là? Méliès, lui, il filmait le voyage sur la Lune, Méliès avait filmé, il filmait, il filmait... la visite du roi de Yougoslavie au président Fallières... et maintenant avec le recul du temps on s'aperçoit que c'était vraiment ça les actualités de l'époque, [...] c'étaient peut-être des actualités reconstituées, dans la manière dont il les faisait, mais c'étaient des véritables actualités. Et je vais même plus loin, je dirais que Méliès, lui, était brechtien [...]. ${ }^{4}$

Léaud's affirmation, which underlines the tension between fiction and documentary, is symptomatic of Godard's cinematic devices. The misunder-

4 I offer a raw translation: Guillaume: "Comrades and friends. Today's topic is newsreels." Audience: "We know them: we see them daily at the movies." G: "Yes, but there's a false idea about current events at the movies. They say Lumière was the first to film current events, that he made documentaries. But meanwhile there was also Méliès, who is said to have made fiction, that he was thus a dreamer filming fantasies. I think just the opposite. [...] and I saw a film by Mr Langlois, the director of the Cinémathèque, about Lumière which proves that Lumière was a painter. He filmed the same things painters were painting at that time, men like Pissaro, Manet or Renoir. [...] He filmed train stations. He filmed public gardens, workers going home, men playing cards, [...] he filmed trams." A: "Had he been one of the last great lmpressionists?" G: "Exactly, a contemporary of Proust. [...] Now, what was Méliès doing at that time? $\mathrm{He}$ filmed a trip to the moon [...] Méliès filmed the King of Yugoslavia's visit to President Fallières. And now, in perspective, we realise those were the current events. [...] They were re-enacted, alright [...] Yet they were the real events. And I'd even affirm that Méliès was like Brechtean.". A partial transcription of the English translation is available in Witt 2013: 23: "Lumière, they say, is documentary, and Méliès is fantasy. But today, what do we see when we watch their films? We see Méliès filming the reception of the King of Yugoslavia by the president of the Republic. A newsreel, in other words. And at the same time we find Lumière filming a family card game in the manner of Bouvard and Pécuchet. In other words, fiction”. The same idea had already been expressed in Godard 1966 and in many other interviews. 
standing is not in fact eliminated but only repeated in its inverted form: the diverted formula conserves the theoretical main sense, namely the fleeting separation between documentary and fictional material. Godard's cinematographic praxis is indeed not attributable to such a dichotomist system, being very often a representation of the world that confounds the simple recording and the elaborated mise en scène. In the mid 1980s, in beginning to work on HistoIRE(S) DU CINÉMA, Godard affirmed: "Tous les grands films de fiction tendent au documentaire, comme tous les grands documentaires tendent à la fiction. [...] Et qui opte à fond pour l'un trouve nécessairement l'autre au bout du chemin" (Godard 1998: 144). Already in the 1960s Godard had observed that he wanted "to do research in the form of a spectacle". "The documentary side", he wrote, "is: a man in a particular situation. The spectacle comes when one makes this man a gangster or a secret agent" and that "reportage is interesting only when placed in a fictional context, but fiction is interesting only if it is validated by a documentary context" (Milne 1972: 192).

\section{Godard'S JOURnalistic CINEMA UNTIL 1967 AND ITS Relationship With the French Cultural IDentity}

The first movie directed by Godard was a 16-minute black and white documentary about the construction of the Grande-Dixence dam, at that time the highest in the world. Entitled OPÉRATION "BÉTON" [1954] and produced by Actua-Films Genève, the movie was sold to the Compagnie de la Grande-Dixence (the company which was holding the dam), allowing Godard to earn a living for almost two years. Exalting French technology and innovation, OPÉRATION "BÉTON" is a documentary which inscribes itself in the field of the national newsreel cinema, and, in July 1958, the short subject was released in France along with Vincente Minnelli's THÉ ET SYMPATHIE. Four years before directing OPÉRATION "BÉTON", Godard, in an article about the Russian cinema of propaganda published in the Gazette du Cinéma, remembered the fascination he had for the newsreel medium: "Un après-midi, à la fin des Actualités Gaumont, nous ouvrions les yeux de plaisir: la jeunesse communiste allemande défilait à l'occasion de la fête du 
$1^{\text {er }}$ mai. [...] Par la seule force de propagande qui les animait, ces jeunes gens étaient beaux" (Godard 1950). 5

After making OPÉRATION "BÉTON", Godard did not direct another traditional documentary, ${ }^{6}$ but we can affirm that apart from this first attempt, his whole cinematic work places itself in the space of ambiguity between fiction and documentary. From his first short movies, and even more starting from his revolutionary first long feature À BOUT DE SOUFFLE [1960], the cinematic work of Godard presents a strong journalistic component both technically and thematically. Speaking about Angéla, the main character of UNE FEMME EST UNE FEMME [1961], a movie shot in part with the actors being prompted through earphones in interviews (cf. Sterrit 1998: 13; 37), Godard admitted that "she does not distinguish between documentary and fiction, just like me" (Beverly Ray 2001: 114); a few years later, asked if he was more concerned with making movies or social commentaries, he answered "I see no difference between the two" (Youngblood 1968: 32).

LES CARABINIERS [1963], a screen adaptation of the theatre piece by Beniamino Joppolo, was shot on Kodak double $\mathrm{X}$ negative stocks in order to create a newsreel effect, in order to mix and confuse the staged scenes with real war fragments. ${ }^{7}$ Similarly to make it appear more "hyperrealistic", LE PETIT SOLDAT [1960] was shot on Agfa Records, a very sensible film mainly used in photographic journalism, and already experimented by Godard's photograph, Raoul Coutard, in the reportages he had produced for Life and Paris Match in the 1950s (Leutrat 2005: 45). In the movie, the main actor, Bruno Forestier, ironically states: "La photographie c'est la vér-

5 Translation by Milne 1972, 16: "One afternoon towards the end of a Gaumont newsreel, my eyes widened in pleasure: the young German Communists were parading on the occasion of the May Day Rally. [...] Purely through the force of propaganda which animated them, these young people were beautiful".

6 Among the partial exceptions, UNE HISTOIRE D'EAU [1958] and the TV series FRANCE / TOUR / DÉTOUR / DEUX / ENFANTS [1979].

7 "The 'staged' sections of LES CARABINIERS were duped several times over in the laboratory until all the greys and shadings were destroyed, and the 'fictional' footage achieved the same verisimilitude [sic] as the old newsreels" (Dixon 1997: 35). The same "realistic" reconstruction attitude is destined to the sounds superposed to the silent newsreels: all the weapons and battle noises are real and come from the objects represented in the frames (Godard 1965). 
ité. Et le cinéma c'est vingt-quatre fois la vérité par seconde"-and maybe Godard has been influenced by the young Kubrick's "photographie style 'actualité' [the newsreel-style camerawork]" (Godard 1958). Censored for three years and released only in 1963, LE PETIT SOLDAT is one of the few films from the 1960s that deals with the "unacknowledged" war of Algeria. Playing with the ambiguity between politics and terrorism, the movie was rejected by both left-wing and right-wing intellectuals, and Godard, answering in the Cahiers du Cinéma some negative critiques, observed that "le film doit témoigner de l'époque. On parle de politique, mais il n'est pas orienté dans le sens d'une politique" (Godard 1962). ${ }^{8}$ Some years before, speaking about LE PETIT SOLDAT, Godard said: "Le sujet n'est pas un sujet actuel mais un sujet d'actualité" (Godard 1960), probably referring to the journalistic "actualités".

Fig. 1: JLG, Still from Ciné-Tract $n .7$

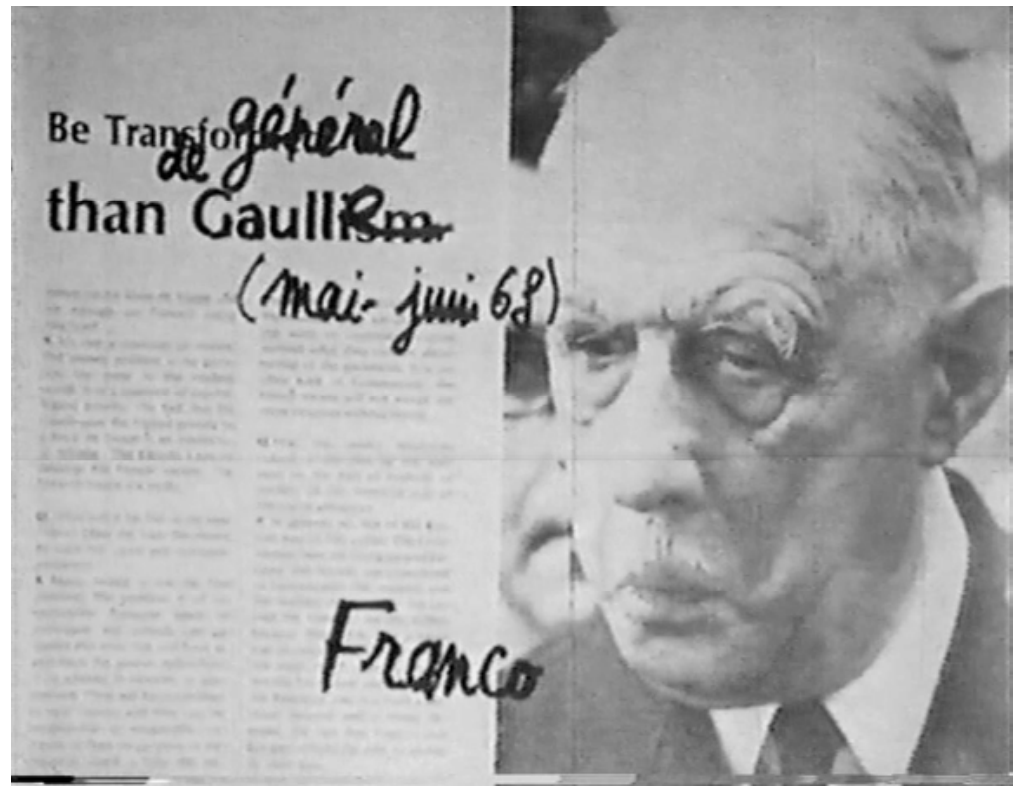

8 See also Gilliatt 1976: "There are films on politics and there are political films. [...] The films on politics records activity, but they are not part of that activity". 
VIVRE SA VIE [1962], Jean-Luc Godard's fourth film, was based on a journalistic account of prostitution in France (cf. Sacotte 1959), probably echoing Samuel Fuller's UNDERWORLD U.S.A. [1961], a movie inspired by a series of articles published in The Saturday Evening Post. Some years later, 2 OU 3 CHOSES QUE JE SAIS D'ELLE [1967] (“elle” being, together with other entities, the Parisian Region), concentrates itself again on the description of prostitution and living in the conglomerations of the suburbs of Nanterres and La Corneuve (already portrayed in LA CHINOISE), again inspired by a report (cf. Vimenet 1966). These movies are often constructed in a paratactic structure, each fragment bearing a number or an intertitle, and already for À BOUT DE SOUFFLE, shot in newsreel-style with a handheld camera in real location scenes [1960], Godard's style of cinema incorporated the idea of the movie as a chaotic litmus paper of society. In fact, scenario and plot are, in À BOUT DE SOUFFLE, only the frame for depicting a couple of young rebels in the early 1960s. Even more, À BOUT DE SOUFFLE-with its minimalistic juxtaposed semi-narratives scenes - is both, as Godard himself affirmed, a documentary about Jean-Paul Belmondo and Jean Seberg in a Godard movie, and, as observed by Sadoul, a "vision de Paris" (1975). Similarly, MASCULIN FÉMININ [1966], shot by the talented documentary/newsreel cinematographer Willy Kurant, is a generational portrait of French youth of the mid-1960s, ${ }^{9}$ while WEEK-END [1967] is defined by a ti-

9 The advertisements for MASCULIN FÉMININ, a feature mainly composed by semi-real interviews with young non-professional actors, list some of the actualités presented in the film: "le sexe et la jeunesse de la France d'aujourd'hui" (Poster, Bergala 2006: 307); "les disques I le Vietnam I le cinéma I les élections | les appareilles à sous | les syndicalisme | la pilule | le coca-cola | les noirs". (Small notice, Brenez 2006: 17). When asked by Caleb Deschanel: "At the end of Masculin/Féminin Paul realizes that all the questions he's been asking as a poll-taker have been false. What does this mean to his ideology? Is he questioning his Marxist ideology as a result? What is it in the interviews that makes him realize this?" JLG answered: "It was simply a critique of poll-taking which is currently very popular in France. All the French magazines have begun to imitate the United States by running statistical polls. What I' $m$ trying to say is that a public opinion poll doesn't have meaning unless there's also a criticism of the values on which it rests. If you're trying to examine public opinion about Ford automobiles and if you're paid by Ford, you'll obviously go about it in a very 
tle card as a film spanning from "la révolution française" to "les weekends UNR".

Godard, who made the pop-art collage a cinematic technique, wishes that cinema could embrace the largest possible range of things, and, above all, depict society in all its aspects, especially the problematic ones. In an article published in 1967 he declared:

"D'ailleurs, si j'ai un rêve, c'est de devenir un jour directeur des actualités françaises. Tous mes films ont constitué des rapports sur la situation du pays, des documents d'actualité, traits d'une façon particulière peut-être, mais en fonction de l'actualité moderne. [...] On peut tout mettre dans un film. On doit tout mettre dans un film. Quand on me demande pourquoi je parle ou je fais parler du Vietnam, de Jacques Anquetil, d'une dame qui trompe son mari, je renvoi la personne qui me pose cette question à son quotidien habituel. Tout y est. Et tout y est juxtaposé. C'est pourquoi je suis tellement attiré par la télévision. Un journal télévisé qui serait fait de documents soignés, ce serait extraordinaire." (Godard 1967)

MASCULIN FÉMININ: 15 FAITS PRÉCIS, which a title card names "Les enfants de Marx et de Coca-Cola, comprenne qui voudra", mixes interviews with actors and real people. Deleuze, assuming some of Godard's statements, observed that "dans MASCULIN FÉMININ, l'interview fictive des personnages et l'interview réelle des acteurs se mêlent si bien qu'ils semblent se parler les uns aux autres, et se parler pour eux-mêmes, en parlant au cinéaste" (Deleuze 1985: 201). Some years before, Godard himself had already affirmed:

"J'ai toujours navigué entre le documentaire et la fiction dans lesquels je ne fais aucune différence ou dont je me sers pour décrire... décrire ça ; toujours osciller entre deux choses ; le cinéma étant quelque chose qui oscille d'un pôle à l'autre et dans le film lui même, mettre des pôles, indiquer des pôles et osciller à des tas d'endroits. [...] J'ai toujours essayé que ce qu'on appelle le documentaire et ce qu'on appelle la fiction soient pour moi les deux aspects d'un même mouvement, et c'est leur liaison qui fait le vrai mouvement." (Godard 1980: 168)

different way than if you were paid by someone else. In a sociological poll you have to be very careful what questions you ask, because they are often influenced by the situation and society you're living in." (Youngblood 1968: 39). 
Even if MASCULIN FÉMININ is a fictional movie inspired by documentary, it is probably the first "cinematographic essay" by Godard. The director does not aspire to make cinéma-vérité and does not aim to produce "direct" documentary, but rather approaches this form with the objective of deconstructing its language and revealing its apparatus. Godard's "cinemaverité", with its high degree of construction-fictional, but filmed as reality with an ésprit du direct-is thus opposed to the "fake reality" of the newsreel and the documentary. Godard is not a naturalistic artist and the strength of his movies comes from transforming the everyday into an artistic creation through abstraction. Edgar Morin observed that:

“Jusque-là, on pensait que l'au-delà de la fiction était le documentaire, et que l'audelà du documentaire était le film de fiction. Ici, avec MASCULIN FÉMININ, nous sommes en même temps au-delà du réalisme de fiction et du cinéma-vérité documentaire, c'est pour moi la première réussite de ce cinéma-essai qui depuis des années se cherche.” (Dauman 1989: 194)

Godard's films are in fact metalinguistic movies more linked with the journalistic language than to an objective reality. To describe the "amphibious realism" of the first long features directed by Godard, scholars and journalists have spoken of "poetic documentary", of "cinematic essay", of "documentary ciné-vérité", and so on. The point is actually the metalinguistic construction of Godard's cinema, which in the early and mid-1960s was intended as a critical description of society: France and its media, seen clearly as a product of the Americanization of Europe. If the cinematic language used by Godard is often linked with journalism, it is also true that this language is deconstructed and that the viewer is almost always reminded of its apparatus via the presence of technical voices in the backgrounds, clapperboards, etc. In other words, with his "newsreels" Godard constitutes a national identity in the sense that this philosophical-linguistic deconstruction is conducted in order to reveal the "spectacle" and give France a cinematic language which could escape the American boundaries, above all politically but also aesthetically.

In 1966 Godard also shot MADE IN USA and the following year he directed 2 OU 3 CHOSES QUE JE SAIS D'ELLE, movies described during the shooting as actualités. Godard observed, stimulated by those two "news reports" movies that: 
"All my films derive from intimate connections with the country's situation, from news documents, perhaps treated in a particular way, but functioning in relation to contemporary reality." (Regard 1966, translated in Lesage 1983: 54)

LOIN DU VIETNAM [1967], shot after 2 OU 3 CHOSES, was a collective effort directed by Joris Ivens, William Klein, Claude Lelouch, Agnès Varda, Chris Marker, Michèle Ray, Alain Resnais, and Godard. It was shot in Vietnam, Cuba, the U.S. and Paris during the spring of 1967. The project, initiated and edited by Marker and composed of personal segments attributed to each filmmaker, represents a violent anti-American indictment of U.S. involvement in Vietnam. Answering a question about his efforts in making FAR FROM VIETNAM, Godard remembered that "It was like making a newsreel and Chris Marker was the editor-in-chief [...]" (Youngblood 1968: 20). Godard's sequence, entitled CAMÉRA-OEIL (aka VIETNAM/GODARD), also directly evokes the newsreel via the voice of the actor/director himself, who, framed manipulating a Mitchell camera, observes that as a French independent filmmaker he was not even allowed to enter Vietnam, while on the other hand if he had been "un cameraman de la télévision du réseau ABC de New York ou de San Francisco, [...] un cameraman des actualités soviétiques", he would have been given permission to shoot scenes of Vietcong bombed by U.S. airplanes.

Even if Godard had already addressed the Algerian conflict in LE PETIT SOLDAT and the Vietnam War in PIERROT LE FOU, and had already filled its screenplays with famous literary and political quotations, it is from the shooting of LA CHINOISE and LOIN DU VIETNAM that Godard begins to show serious interest in the political movements around the world, such as the Vietcong Party and the Chinese cultural revolution. Between 1968 and 1970 - years marked by a militant third-worldism and by the research of "situations concrètes"-Godard visits London, Cuba, the U.S., Québec, Czechoslovakia, Italy and Palestine. Godard's flirt with Marxism and Maoism really began during the summer of 1968, but LA CHINOISE [1967] and LE GAI SAVOIR [1968], ${ }^{10}$ already fully political, introduced his radical turn

10 LE GAI SAVOIR was co-produced by ORTF, but after the movie has been completed the TV channel refused Godard's feature, and it was also censored in French cinemas. LOTTE IN ITALIA [RAI, Dec 1969] and BRITISH SOUNDS 
prophesising the events of May 1968 and expressing an explicit and vehement critique to the Western contemporary society. At the Los Angeles Free Press conference of March 8 1968, answering Toby Mussman's question about what he thought "of the New American Cinema, or the so-called underground" and if there was an equivalent in Europe, Godard observed:

"To me, $[\ldots]$, the term 'underground' is silly, because the only true underground in the world today is North Vietnam. Instead of underground, I would prefer a term such as 'Third World Cinema'. Why? Well, because to me the underground is to the cinema of Hollywood what the new revolutionary politics is to established order." (Youngblood 1968, now in Sterritt 1998: 11)

Two years later, after having visited the U.S. to shoot a political movie, his judgement about the American underground cinema became more critical: in April 1970, after having decide not to edit his American movie, he declared to Andrew Sarris that the Newsreel Group's cinematic methods were incorrect, because

"They shot nothing but the standard CBS stuff - cops beating up students, the students retaliating. Just like a network series. Not even with Jerry Rubin's sense of humor. But a revolutionary filmmaker doesn't merely show a strike. He explains what is behind it." (Sarris 1970: now in Sterritt 1998: 55-56)

\section{Godard's Militant Cinema AROUNd 1968 AND the Critique of the Cinematic Language OF JOURNALISM}

The 17th of May 1968, Claude Berri, Milos Forman, Macha Méril, François Truffaut and Jean-Luc Godard, embracing the cause of the May ' 68 revolution, removed their movies from the 21 st annual Festival International du Film of Cannes, causing its sudden end on the 19th of May at 12 AM, five days before the official closing ceremony. Godard, from the stage

[LWT, Feb 169] are others projects refused at the end by the respective commissioner TV stations. 
of the Grand Salon, explained that the strike was more than symbolic, denouncing the fact that:

“Il n'y a pas un seul film qui montre des problèmes ouvriers ou étudiants tels qu'ils se passent aujourd'hui, il n'y en a pas un seul, qu'il soit fait par Forman, par moi, par Polanski, par François, il n'y en a pas. Nous sommes en retard. Nos camarades étudiants nous ont donné l'exemple en se faisant casser la figure il y a une semaine." (Godard 1998: 50) $)^{11}$

While Godard was making this speech at Cannes, students from Paris asked Chris Marker to join the increasingly revolutionary action by shooting agitprop movies that spoke to the current social upheaval, which were ignored if not criticised by the official national information. In answer, on the 19th of May 1968, Les États généraux du cinéma was formed, uniting approximately 1,500 people, professionals or those not in cinema, with the aim of "faire politiquement des films politiques" ["making political the political films"]. Resnais, Truffaut, Marker and Godard, among others, took part in the May 1968 action by filming political short movies called CINÉ-TRACTS or FILM TRACTS.

11 A video of the speech is available at http://fresques.ina.fr/festival-de-cannesfr/fiche-media/Cannes00254/festival-de-cannes-mai-1968.html [June 15 2016]. 
Fig. 2: JLG, Still from Ciné-Tract n. 12

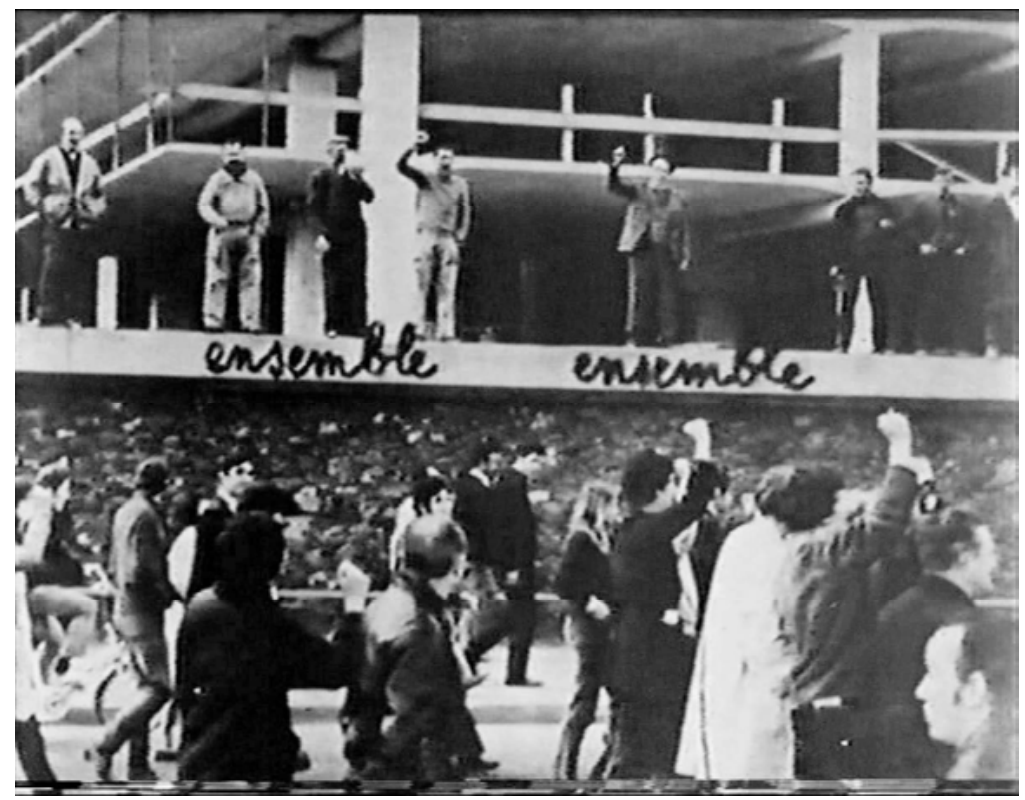

Black and white three-minute movies, almost always silent, CINÉ-TRACTS were often composed of photos or stills with taglines and subtitles. ${ }^{12}$ Produced by $\mathrm{SLON}^{13}$ with the aim of immediate diffusion, the tracts, for a total of more than hundred works, were compiled in $16 \mathrm{~mm}$ reels to be sold at the production cost (which at the time was fifty French francs) and widely dis-

12 Each of the CINÉ-TRACTS should have consisted of 100 feet of $16 \mathrm{~mm}$ black and white silent film shot at 24 FPS, equalling a projection-time of 2 minutes and 50 seconds. As the cutting was normally being done at the time of shooting (this technique was imposed by a collective choice), CINÉ-TRACTS were not post-produced in the editing room. The director was expected to self-produce, self-edit and be the cinematographer, ensuring furthermore that each film was shot in one day. As in Marker's LA JETÉE [1962], these films rely almost exclusively on stills rather than documentary video footage, approaching the form of a didactical photo-story composed of images and texts.

13 Société pour le Lancement des Euvres Nouvelles, named ISKRA [Image Son Kinéscope et Réalisations Audiovisuelles] from 1974. 
seminated. Shot in the spring of 1968, the tracts were screened in student assemblies, factories and political action committees. Due to the filmmakers' anonymous approach to the ciné-tracts project, as well as the collaboration between directors, technicians and amateurs, the CINÉ-TRACTS do not include any information to identify who made them. Despite the anonymity, though, we can often detect the hand of a particular director: in the case of Godard, identification is made easier by the presence of his distinctive cursive handwriting: at least eleven CINÉ-TRACTS exhibit Godard's calligraphy on the title cards or directly upon the images themselves. ${ }^{14}$

Fig. 3: JLG, Still from Ciné-Tract n. 40

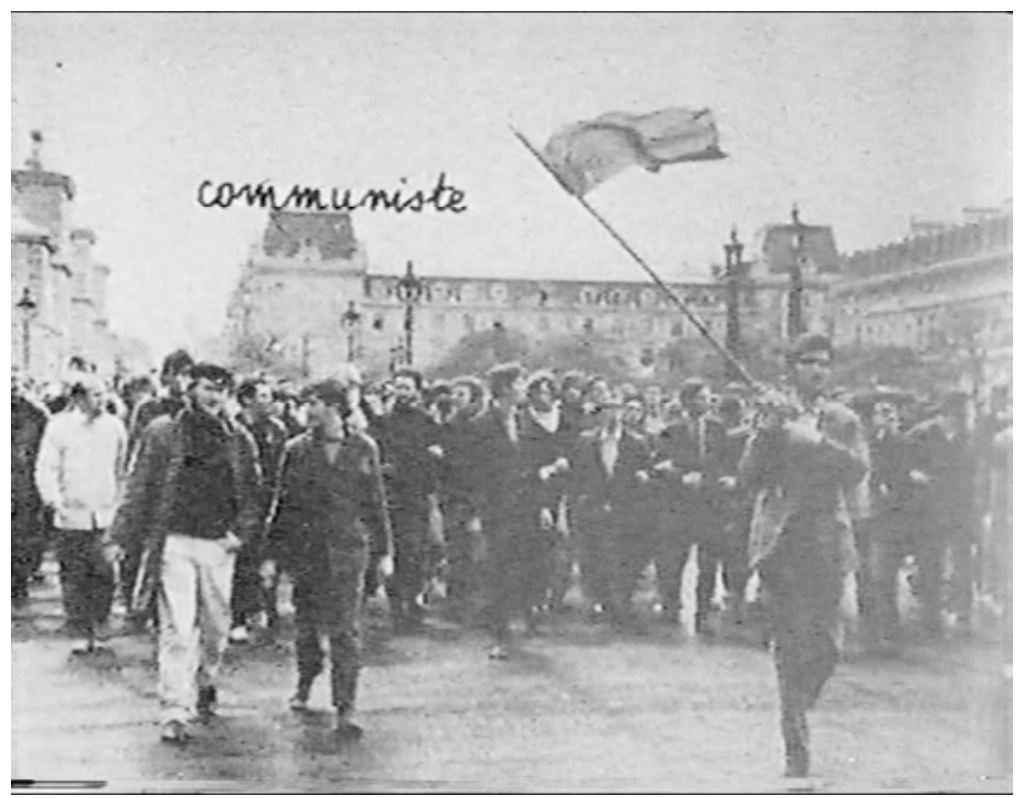

14 The titles of the FILM TRACTS n. 7-10, 12-16, 23 and 40 are written by Godard's hand and present the same lettering, except $n$. 16, which has been presumably written faster, and with a different marker. Those titles are written on boxes of Eastman Double-X 7222 films, the one used by Godard to shoot his tracts, except n. 23 and 40, written on two boxes of Eastman 4-X negative 7224 reels. 
Together with the special issue FILM TRACT N. 1968, the tracts we know to have been shot by Godard are numbers 7-10, 12-16, 23 and 40. The graphic political art produced throughout the May ' 68 revolts frequently used text as a means of détournement, the repossessing of an image for different ideological, political or artistic purposes than that for which it was created, a term originally devised by Isidore Isou and the Lettrists and then by Guy Debord and the Situationist International. This technique is attained by textually inscribing an image to reflect revolutionary ideology or subvert its originally imposed meaning, and other times contrasting binary images to produce an imaginary third one: "Take a photo and statement by Lenin or Che, divide the sentence into ten parts, one word per image, then add the photo that corresponds to the meaning either with or against it" (Godard 1968). ${ }^{15}$ Godard's works with the CINÉ-TRACTS is in a genre that should be informational and documentary (thus near to the newsreel), but his personal contributions are not at all. They differ from the more traditional militant messages of 1968 because their pragmatic aim is not just agitation or counter-information. Godard's tracts, indeed, show not reality but, with techniques often very close to those of visual poetry, constitute a philosophical critique of the language of the power not so far from the "semiological guerrilla", widely theorized the previous years by, among others, Umberto Eco (1967) and McLuhan ([1964] 1995).

15 A similar revolutionarily elementary approach to images and words is also evoked in Sarris (1970: 58): "Godard explained the austere aesthetic of SEE YOU AT MAO [1970] in terms of an interesting dialectic of image and sound: 'I keep my image simple as opposed to Hollywood' (Hollywood for Godard is virtually everything except Godard and Mao.) 'Hollywood provides many images and not enough sound, many pictures but few words. We in France saw nothing of Algeria on television, but the Word was powerful enough to mobilize us against the Algerian War. Here in America, you see many images of Vietnam on television, but few words to explain the situation. Even the slogan 'get out of Vietnam' is completely out of date because Nixon is carrying the war to Laos and Cambodia. It's better to have no images than too many. The Chinese don't have millions of books like us. They have only one, and that's all they need". 
Fig. 4: JLG, Still from Ciné-Tract n. 40

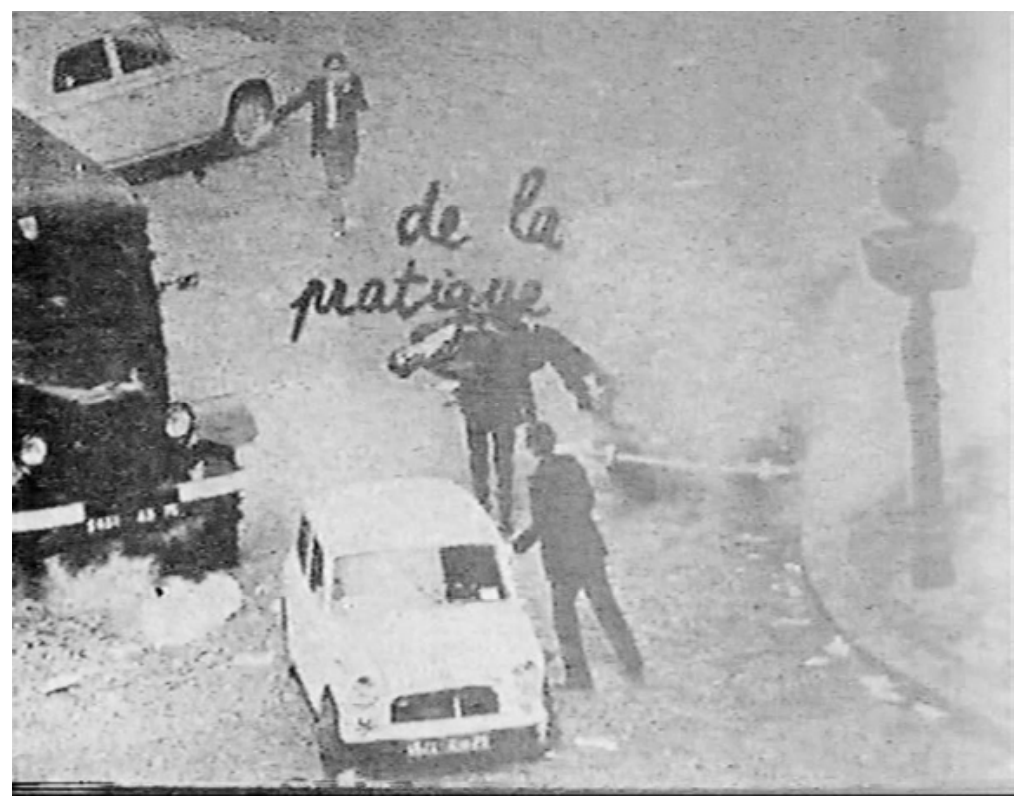

Film-TRACT N ${ }^{0}: 1968$ (often called Le RoUGE), a special issue of the tracts series, is a cinematic version of a poster created by Gérard Fromanger during the Ateliers Populaires de l'Ecole des Beaux-Arts workshop, out of which came the most famous graphic symbols of May '68 (cf. Fromanger quoted in: Brenez 2001: 335-338). After a handwritten title (on a page of $L e$ Monde with the title "Contestation" underlined!), the first frame is completely red, then the zoom out shows that the red is paint being slowly poured over a white surface. The zoom out continues, showing the red paint spreading on the white and the blue stripes of a three-colored French flag canvas laying on some newspaper; then the film zooms back in to the flag, which, centered in the photo-frame, appears in its final immobility (the credit "Réalisation technique Gérard Fromanger, Jean Luc Godard" ends the tract). The symbolic political value of the revolutionary red covering the other surfaces is here obvious.

1968 is also the restless year in which Godard, together with Jean-Pierre Gorin, founds the Group Dziga Vertov (GDV), a Marxist collective devoted to the creation of revolutionary movies. Concerning the collective's name, 
we should remember that an opposition between "fathers" similar to that between Méliès and Lumière was also applied to the figures of Eisenstein and Vertov. ${ }^{16}$ The two, treated almost as opposite poles, embodied, for Godard the two directions of cinema, Eisenstein representing the "artistic" form (and consequently a reactionary bourgeois product), and Vertov the "materialistic" and avant-gardist, therefore militant and progressive, cinema. In an interview given to Kent E. Carroll in 1970, Godard explained the symbolism of Vertov's name:

"The group name is meant to indicate a programme, to raise a flag, not just to emphasize one person. Why Dziga Vertov? Because [...] he was a really Marxist moviemaker [...] He wasn't just an artist. He was a progressive artist who joined the revolution and became a revolutionary artist through struggle. He said that the task of the kinoki was not moviemaking [...] but to produce films in the name of the World Proletarian Revolution." (Carroll 1970, now in Brown 1972: 50)

Following Godard in the years 1968-1972, Eisenstein's dialectic-trying via the editing to develop its revolutionary effect while remaining embedded in the traditional cinematic theatre-still represents a reactionary form of bourgeois dramatics "reconstruction", while Dziga Vertov comes to revolutionize not just the contents of the cinema but its form itself ("Voir et montrer le monde au nom de la révolution soviétique”). Quoting Mao, Godard says in LA CHINOISE that:

“Nous exigeons l'unité de la politique et de l'art, l'unité du contenu et de la forme. L'unité du contenu politique révolutionnaire et d'une forme artistique aussi parfaite que possible. La seule œuvre qui manque de valeur artistique, quelque avancée qu'elle soit au point de vue politique reste inefficace. Nous devons, en littérature et en art mener la lutte sur deux fronts."17

16 Godard is, however, too much of an anarchist to center on a fixed theory, and the name of Eisenstein, outside the period around the GDV, is evoked more favourably.

17 See also Godard 1967b. Mao's speech, in English as follows: "What we demand is the unity of politics and art, the unity of content and form, the unity of revolutionary political content and the highest possible perfection of artistic form. Works of art which lack artistic quality have no force, however progres- 
This way of "making films politically" is more than a concern of aesthetics or production; it is also ideological, and Godard affirmed in 1972 that "a movie is not reality, it is only a reflection. Bourgeois filmmakers focus on the reflection of reality. We are concerned with the reality of that reflection" (Carroll 1970: 83). The militant movie proposed by Godard is opposed to the "film "Internationale", the archetypal Communist propaganda movies produced by Mosfilm, the Sovietic equivalent of Hollywood, judged to be "revisionist".

"Il y a deux sortes de films militants : ce que nous appelons les films 'tableaux noirs' et les films 'Internationale', celui-ci qui équivaut à chanter l'Internationale dans une manif, l'autre qui démontre et permet à quelqu'un d'appliquer dans la réalité ce qu'il vient de voir, où d'aller le récrire sur un autre tableau noir pour que d'autres puissent l'appliquer aussi." (Godard 1998: 348) ${ }^{18}$

The blackboard movies differ from traditional propaganda movies in that they avoid the Russian-American format of cinematic propaganda and deal with the construction of an active political thought, turning the film screen into an interface for consideration and debate rather than a medium for passive consumption.

The period which encompassed the end of 1968 and the Dziga Vertov Group is that in which Godard created a revolutionary cinema on the basis of political theory and militant journalism. The DVG movies demonstrate thus an internationalist interest in the foreign struggles. ONE AM [ONE AMERICAN MOVIE], the unfinished PBL 1968 project then produced, realised and edited by D. A. Pennebaker and R. Leacock, under the name ONE PM [ONE PARALlel MoviE] [1972], contained a long segment about the Black Panther Party (a secondary subject of ONE PLUS ONE [1968]). UN FILM COMME LES AUTRES [1968] shows discussion between French workers

sive they are politically. [...] We must carry on a struggle on two fronts" (TseTung 1942).

18 I offer here my translation: "There are two kinds of militant movies: those we call 'blackboard films' and those known as International features. The latter are the equivalent of chanting L'internationale during a demonstration, while the former prove some theories that allow one to apply to reality what he has seen on screen, or in order to make others abide by it." 
and students, while the Palestine Liberation Front is portrayed in the never completed movie JUSQU'À LA VICTOIRE [1970]. The opening narration of BRITISH SOUNDS [1969], another TV commission about the political situation of workers in the UK, speaks about the new-born Godardean science of image, stating reference points such as the opposition of "documentaire/fiction". Two other television commissions followed the same year: After PRAVDA [1969], shot in Czechoslovakia and commissioned by the National Party, and LotTE IN ITALIA [1969], shot between Paris and Italy and commissioned by RAI, both of which were rejected by the respective productions. Frustrated with the situation, Godard told Andrew Sarris:

"We made a movie and they criticized it. It was a disaster, and we tried to find out why it was a disaster. [...] We are always learning. The important thing is to look at film from a political point of view rather than an individual point of view. Anyway, Czechoslovakia had been invaded by American tanks from United Artist long before the Russians came in." (Sarris 1970, now in Sterritt 1998: 55)

After the flops of PRAVDA and LOTTE In ITALIA, Godard and Gorin abandoned the anti-fictional format and returned to a Brechtian theatrical fiction to produce LE VENT D'EST [1970], the real manifesto of the GDV, which was followed by VLADIMIR ET ROSA [1970] and TOUT VA BIEN [1972]. The research on the medium was in any case not ceased and in 1973 Godard spoke of TOUT VA BIEN as "a white blackboard":

"What you learn from TOUT VA BIEN depends on your background and your condition of life. We like to consider the screen as a blackboard, a white blackboard. On this blackboard we put three elements, three social forces, which are represented by three 'noises'. The management, the voice of the boss; the CP voice; and the leftist voice - I don't like to call it that, let's say the voice of the far-out people. These are the three social forces at work in France today. We have taken those three noises out of reality. We didn't invent them, we just assembled them in a certain order. In fact this movie is just a newsreel. In a way we summed up the last two years in France in an hour and a half." (Koller 1973: 132)

"Enquête sur une image" (Godard 1972), presented to the reader of "Tel Quel" Godard and Gorin's original French version of the fifty-minute speech contained in LETTER TO JANE [1972], the more cerebral GDV fea- 
ture. The movie consists of a critical response to a newspaper photograph of Jane Fonda (who was the main actress in TOUT VA BIEN) talking to North Vietnamese people. ${ }^{19}$ The movie is composed mainly of stills: the camera is set for long periods on the photograph, occasionally switching to other photos or movie stills, while Godard and Gorin discuss, among other things, the implications of Fonda's facial expression and why that photo was so widely distributed in European newspapers. One of the main theses of the contribution was "la necessité pour le capital de masquer le réel au moment même où il le démasque" (Godard 1972: 81).

His experience as a Marxist revolutionary allows Godard to bring the revolution inside the cinema, undermining socialist realism. This is to say that Godard produces a counter-information that is not simply 'information against information' but also a critique of communication and information as languages. LA CHINOISE's pressbook, distributed during its first screening in Avignon, presented a manifesto against the hegemony of American (and other majors countries') cinema:

"MANIFESTE. Cinquante ans après la Révolution d'Octobre, le cinéma américain règne sur le cinéma mondial. Il n'y a pas grand-chose à ajouter à cet état de fait. Sauf qu'à notre échelon modeste nous devons nous aussi créer deux ou trois Vietnams au sein de l'immense empire Hollywood, Cinecittà, Mosfilms, Pinewood, etc., et tant économiquement qu'esthétiquement, c'est-à-dire en luttant sur deux fronts, créer des cinémas nationaux, libres, frères, camarades et amis." (Godard 1998: 303) ${ }^{20}$

19 L'Express, 31 July 1972. The photo appeared with the title: "Jane Fonda interrogeant des habitants de Hanoï sur les bombardements américains". See also Koller: RPK: "We think we can use videotape to communicate with people" JLG: "To communicate what? What kind of information? We can't speak of information per se, in heaven. In our still of Jane Fonda we have seen how in information there is a process. There is a very strong relationship between the cheapness and the cost of information." (Koller 1973: 131)

20 Press book for LA CHINOISE, 1967, reproduced in Brenez 2006: 88, translation in Milne 1972: 243: "Fifty years after the October Revolution, the American industry rules cinema the world over. There is nothing much to add to this statement of fact. Except that on our own modest level we too should provoke two or three Vietnams in the bosom of the vast Hollywood-Cinecittà-MosfilmPinewood- etc. empire, and, both economically and aesthetically, struggling on 
To fight this tendency Godard proposes a kind of Cinematic International formed by the national cinemas in order to counter the imperialistic American civilization. For Godard, mainstream cinema has become an instrument of capitalistic power, a centralised imposition of a standard of ideologies, values and ideas:

“Le Centre [National du Film], c'est le kapo. [...] C'est un organisme politique nuisible à la fois à l'industrie et à l'esthétique du cinéma. C'est aussi ce qui fait que, même en Russie, le cinéma est devenu ce qu'il est... C'est bien un cinéma d'Etat, mais au plus mauvais sens du terme, dans la mesure où il a été nationalisé sur les idées mais pas sur la forme [...] Sans compter que là comme ailleurs, on importe ce qu'il y a de pire dans le cinéma occidental. [...] Si j'ai une définition du cinéma, c'est celle-là: le cinéma est devenu l'agit-prop du capitalisme.”(Godard 1967b: 26)

Visiting California the following year, he insisted: "I see no difference between Russian and American movies. They are both bad" (Youngblood 1968: 13). ${ }^{21}$ The didactic aim of the blackboard movies was somewhat continued by Sonimage, a production and distribution company established in 1973 by Godard and his wife Anne-Marie Miéville and described by the former as "une societé d'information. [...] Le but est de faire de l'information au sens large, allant plus vers la fiction que vers le documentaire. Etre un AFP du spectacle. Pour moi l'information ça serait cela" (Godard 1975: 11). The metalinguistic aspect that appeared in the early 1960s, denouncing the clichés and the language that composed the nouvelle vague cinema, became in the late 1960 s the central discourse of the features, resurfacing in the television reports of the late 1970s.

One of the first products of Sonimage is ICI ET AILLEURS [1974], a reworked version of the footage of JUSQU'À LA VICTOIRE [1970], the nevercompleted GDV's project documenting a PLO group. Even on this occasion, Godard calls into doubt the veracity of the film's production demonstrating how he had manipulated his own footage, such as when he used a close-up to conceal the fact that a Lebanese woman, explaining how proud

two fronts as it were, create cinemas which are national, free, brotherly, comradely and bonded in friendship."

21 See also Godard's observations on Eastern Communist cinema in Sterritt 1998: $21-22 ; 32 ; 55$. 
she was to be bearing a child that might one day reinforce Palestinian troops, was in fact clearly not pregnant. In 1976, Sonimage commissioned a TV-series of six double episodes to be shown on FR3 Sundays evening between 25 July and 29 August that year. The 600 minute-long TV program, shot in three months and entitled SIX FOIS DEUX / SUR ET SOUS LA COMMUNICATION [1976], was mainly focused on the relationship between medium and message, and aroused the interest of Gilles Deleuze, who was following Godard's experiments at the time and was inspired by his praxis. ${ }^{22}$ Between the end of 1977 and the beginning of 1978, Sonimage presented FrANCE / TOUR / DÉTOUR / DEUX ENFANTS, another TV series composed of a dozen of episodes of about 26 minutes each. The twelve-part project for and about television, commissioned by ANTENNE 2 and produced in partnership with the Institut National de l'Audiovisuel, deals with philosophy and sociology. It offers a study of the effect of television on contemporary French families and is constructed around Godard's interviews with Camille and Arnaud, a young girl and boy representing the new middle-class French youth. In the same year, Godard and Miéville travelled to Mozambique on the invitation of the new independent government to advise the latter on the start-up of a national broadcast television system. Godard wanted to use the experience as raw material from which to produce a video project which was to be named either NORD CONTRE SUD or NAISSANCE (DE L'IMAGE) D'UNE NATION (cf. Fairfax 2010) and would deal with the problems of the new national approach to moving images.

JLG: "I [...] have a project [...] in Mozambique. [...] In Mozambique, the image is the raw material. [...] They're beginning TV there and are afraid of following the paths of everyone else. They have a small cinema institute, built on Cuban model, but it's too theoretical for Mozambique. The government wants to make the movies work in conjunction with TV, like brother and sister. So we have a two-year contract to go six or seven times to talk, study and make films. (Cott 1980, quoted in: Sterritt 1998: 95)

22 A brief survey of Godard's relationship with contemporary French philosophy can be found in Giovannoli 2013. 


\section{Histoire(s) du Cinéma and the National Cinemas}

Summing up our short survey, if Godard started defining a national French identity via the bias of his journalistic-fiction movies, from the very beginning he questioned not only the system he was portraying but also the language of the information media itself. In his Marxist period, this critique attacked the globalized language of the US, bringing Godard's cinema in the direction of a new, autonomous national cinema.

Gavin Smith: "Yet your kind of filmmaking has always represented a countercinema."

JLG: “Today it is in fact against, but I don't worry about it anymore. When I'm making a big film. I don't say to myself, it's against this kind of Hollywood picture, this kind of French picture - it's just the picture I'm doing. I know that I'm definitely the opposition, but it's a big land, too." (Smith 1996, quoted in: in Sterritt 1998: 179)

In 1982, commissioned by the City of Lausanne on the occasion of its 150th anniversary, Godard shot the poetical-philosophical "documentary" LETTRE À FREDDY BUACHE [1982], but generally the 1980s represented for him a return to somewhat more mainstream narrative cinema. This period is marked by traditional fiction movies such as SAUVE QUI PEUT (LA VIE) [1980], Passion [1982], PrÉnOM CARMEn [1984], Je vous salue, Marie [1985], GRANDEUR ET DÉCADENCE D'UN PETIT COMMERCE DE CINÉMA [1986]. If the 1980s were marked by some attempts at fiction cinema, Godard never ceased to write articles and texts about the relationship between cinema, fiction, documentary and power.

At the end of the decade, after the experimental KING LEAR [1987], Godard returned to the newsreel and to explicit reflection on the cinematic language with HISTOIRE(S) DU CINÉMA [1988-1998], an examination of the history of cinema and its relations with the 20th century as well as a critique of the 20th century and how society has perceived it through movies. This 8-part 266 minute video project, begun in the late 1980s and completed in 1998, demonstrates Godard's partially new attitude toward cinema. Unlike the journalistic-pop surveys of the early and mid-1960s, the didactic agit-props produced after 1967 and the communicational essays produced by Sonimage, HISTOIRE(S) DU CINÉMA represents a more placid and reflex- 
ive discourse about cinema as spectacle. If the tracts were produced with the intention of demystifying medias and changing society, the four double episodes of HistoIRE(S) were conceived to analyse the Western history of the 20th century through Western cinema production, and vice versa.

The first episode of the HISTOIRE(S), entitled "CHAPITRE UN (A) TOUTES LES HISTOIRES", reproduces scenes of newsreels footages and obsessively refers to Nazism and the Holocaust. One of the first phrases of the film, "histoires du cinéma | actualité de l'histoire | histoires des actualités | histoires du cinéma I avec des s I des SS" (Godard 1999, 1a: 10),23 connects the newsreel and the fiction cinema through emphasis of their usually common political goals. Katherine Dieckmann (1993: 66) observes a sequence of Histoire(S): "gritty newsreel footage of war mingles with an image of the 20th Century Fox logo and its sweeping klieg lights, with the none-toocovert message that these forms of spectacle aren't completely separate".

Not only "tous les grands films de fiction tendent au documentaire, comme tous les grands documentaires tendent à la fiction" (Godard 1998: 144), but the power that produces Hollywood fiction (the consensus-maker of the capitalist system) is the same that constructs "la bataille de Bagdad I racontée par CNN I le triomphe de la télévision américaine I et des ses groupies (Godard 1999, 3a: 8). ${ }^{24}$ Newsreel and cinema can be seen as the two faces of the same system, and are treated in similar critical and deconstructivist manners, having been picked up on one hand as an "evident proof" and on the other as fragments of a more complex syntax and meaning created by the collage-director himself. The cutting used to connect or oppose images (and sounds) is used in HISTOIRE(s) to show and demystify the inner ambiguities of cinema. In 1994 Godard wrote, clearly pointing to the Hollywood system: "La beauté, le maquillage. Dans le fond, le cinéma n'a jamais fait partie de l'industrie des communications ni de celle du spectacle, mais de l'industrie des cosmétiques, de l'industrie des masques, succursale elle-même de l'industrie du mensonge" (Godard 1994; cf. Godard 1999, 1b: 47). Great movies are for Godard those that allow a nation to truly "look at itself", movies which analyse society and are not used to impose

23 English translation in Godard 1999, 1a: 38 : "history(ies) of the cinema I news of history I histoires des actualités I histoires du cinema I with esses I with SSes".

24 English translation in Godard 1999, 3a: 32: "[...] the battle of Baghdad I as told by CNN I the triumph of American television I and its groupies". 
thoughts from above. Godard's cinematic language and Marxist ideology are complementary, organised inside a critique of the American globalization of cinema. Even if HistorRe(s) is mainly focused on American, French, Italian and German cinema, its title, in a plural form, could also be directed towards the idea of a cinema seen from the point of view of plural nationalities. ${ }^{25}$ But a simply "not-American" national cinema is not enough if it lacks truth, and indeed, Godard has never tried to produce a real civic cinema, also because, as he affirmed to MacCabem, the good movies produced after 1945 were a response to the need for the European nation to show "reality in a new way through a new form" (MacCabe 1992: 101). Also, evoking similar observations by Bazin and Deleuze, Godard says that:

"Movie-making at the beginning was related to the identity of the nation and there have been very few 'national' cinemas. In my opinion, there is no Swedish cinema but there are Swedish filmmakers - some very good ones, such as Stiller and Bergman. There have only been a handful of [national] cinemas: Italian, German, American, and Russian. This is because when countries were inventing and using motion pictures they needed an image of themselves.” (MacCabe 1992: 98)

In this sense, the cinematic medium is a mirror with which one can look at oneself in order to discover, not only in a historical sense or in a diachronic way, but also through daily consumption, one's own, inner identity:

“[...] le seul film au sens de cinéma I qui a résisté à l'occupation du cinéma I par l'Amérique I à une certaine manière uniforme I de faire le cinéma, ce fut un film italien I ce n'est pas par hasard I l'Italie a été le pays I qui s'est le moins battu I qui a beaucoup souffert I mais qui a trahi deux fois I et qui a donc souffert de ne plus avoir d'identité I et s'il l'a retrouvée avec ROME, VILLE OUVERTE I c'est que le film était fait par des gens sans uniforme I c'est la seule fois I les russes ont fait des films de martyre I les américains ont fait des films de publicité I les anglais ont fait ce qu'ils font toujours I dans le cinéma I rien I l'Allemagne n'avait pas de cinéma I plus de cinéma I et le français ont fait SYLVIE ET LE FANTÔME I les polonais ont fait deux films

25 In a monologue of LE PETIT SOLDAT, Michel Subor says: "C'est drôle, aujourd'hui tout le monde déteste les français. Moi je suis très fier d'être français, mais en même temps, je suis contre le nationalisme. On défend des idées, on ne défend pas des territoires". 
d'expiation | [...] | et un film de souvenirs, [...] | tandis qu'avec ROME, VILLE OUVERTE I l'Italie a simplement reconquis le droitl pour une nation de se regarder en face I et alors est venue l'étonnante moissonl du grand cinéma italien." (Godard 1999, 3a: 12-14) $)^{26}$

During almost seven decades of making cinema, Godard has experimented with different forms of struggle with, or resistance to, the American globalizing cinema. This is particularly true from the decade after 1968, which had embraced the various national liberation fronts, then Vietnam and Palestine and afterwards the independent Québec, making a new critical kind of cinema not enslaved by national or nationalistic models but nevertheless capable to constitute free national identities, or a new "Cinematic Internationale". Even today, Godard's journalist-cinema, through denouncing the capitalist and globalised system and its refusal to deal with the features market, pitches in against American globalization, and by being therefore politically and cinematically anti-colonialist creates national movie resistances.

Gavin Smith: "What moments defined that fall [of the cinema as a medium, as described in GERMANY YEAR 90]?"

JLG: "The First World War and the Second World War. World War I was an opportunity for American cinema to beat French cinema, which at the time was more

26 English translation in Godard 1999, 3a: 36-37: “[...] the only film in the cinema sense I that resisted the occupation of the cinema I by America I a certain uniform way I of making cinema, was an Italian film I it wasn't by accident I Italy was the country I that fought least I that suffered greatly I but that twice changed sides I and therefore suffered from loss of identity I and the reason it got it back with ROME, OPEN CITY I was that this film was made by people out of uniform I that was the only time I the Russians made films of martyrdom I the American made advertisements I the British did what they always do I in the cinema I nothing I Germany had no cinema I and the French made SYLVIE ET LE FANTOME I the Poles made two films of expiation I [...] I and a film of memoirs, [...] I while with ROME, OPEN CITY I Italy simply reconquered the right I of a nation to look itself in the eye I and there followed the astonishing harvest I of great Italian cinema." Godard is here dialoguing with André Bazin's essay Le réalisme cinématographique et l'école italienne de la libération. 
powerful and well known. Pathé, Gaumont, Méliès; Max Linder was a huge star. The French were weak after the war, and it was a way for Americans to disembark in European cinema for the first time. And they had linked to German cinema. Half of Hollywood was filled with [Germans]; Universal was founded by Carl Laemmle. The Normandy beaches were the second invasion, World War II was a way to take Europe definitively. And now, as you see in politics, the way Europe is incapable of doing anything without the OK of the U.S. government, now in the movies America has taken control of the whole planet. So what was democratic in a lot of ideas disappeared at a time that I will study in my next [HISTOIRE(S) DU CINEMA] - a very specific time, with the fact of the concentration camp, that it was not shown [by cinema], it wasn't answered.” (Smith 1996, quoted in: Sterritt 1998: 180)

But Histoire(S) adds to all that a new element, which is in reality-as the reference to ROMA, CITTÀ APERTA suggests-Godard's return to his neorealist roots: the idea that the "poor newsreel cinema" could purify national cinemas, free them from their masked ideology and bring them back to truth:

c'est le pauvre cinéma des actualités I qui doit laver de tout soupçon I le sang et les larmes I comme on nettoie le trottoir I lorsqu'il est trop tard I et que l'armée a déjà tiré sur la foule II ce qu'il y a de cinéma dans les actualités de la guerre I ne dit rien I il ne juge pas I jamais de gros plans I la souffrance n'est pas un star I ni l'église incendiée I ni le paysage dévasté I|| l'esprit de Flaherty et celui de Epstein I ont pris la relève I et c'est Daumier I et c'est Rembrandt I avec son terrible noir et blanc III peu de panoramiques I une plongée peut-être I mais c'est parce qu'une mère I pleure l'enfant assassiné [...] || et si George Stevens n'avait utilisé le premier I le premier film en seize couleurs I à Auschwitz et Ravensbrück | jamais sans doute | le bonheur d'Elizabeth Taylor I n'aurait trouvé une place au soleil || trente-neuf quarante-quatre I martyre et résurrection I du documentaire (Godard 1999, 1a: 14 et seqq.). ${ }^{27}$

27 English translation in Godard 1999, 1a: 42: "it's the poor news cinema I that has to wash clean of all suspicion I blood and tears I just as the pavement is swept I when it's already too late I and the army opened fire on the crowd II what there is of cinema in war newsreels I says nothing | it doesn't judge I never in close up | suffering is not a star I nor is a burned church I nor a devastated landscape II the spirit of Flaherty and that of Epstein I have taken over I and it's Daumier I and it's Rembrandt I with his terrible black and white I| few panning shots I perhaps a 
After so many years of criticizing the information media, a real declaration of love to the newsreel! In more recent years Godard continued to work with the newsreel form, emulating or integrating it in his cuttings, collages and superimpositions, as for example in ALLEMAGNE ANNÉ 90 NEUF ZÉRO [1991], De L'ORIGINE DU XXIÈ SIÈCLE [2001], Notre MusiQue [2004], and in the third episode of FILM SOCIALISME, entitled NOS HUMANITES [2010], and in ADIEU AU LANGAGE [2014]. Because, in fact, if information and show are two sides of the same coin, it is within the "poor newsreel" that the apparatus is normally less present (or clearly exposed), permitting this humble form of identity construction to remain more pure than its more "fictional" counterpart. Furthermore, the raw material of the newsreel offers the cinéphile (and the historian) an analysis of "the interrelationship of films, national identity, and the construction of nationhood" (Witt 2013: 135), those relationships being obviously mutual.

For Godard, moreover, the newsreel format has also conserved the same "light" of the good old cinema of the 1930s through the 1960s, the poetry of a definitively lost world, which he strongly (at least cinematically) regrets. After all, in 1972, summing up his twenty years of critical and cinematic actions and prophesising the more than forty years that would have followed, Godard stated:

"Generally speaking, reportage is interesting only when placed in a fictional context, but fiction is interesting only if it is validated by a documentary context. The Nouvelle Vague, in fact, may be defined in part by this new relationship between fiction and reality, as well as through nostalgic regret for a cinema that no longer exists." (Milne 1972: 192)

\section{References}

Bergala, Alain, et al. (2006): Godard au travail. Les années 60. Paris: Cahiers du cinéma.

high angle shot I but it's because a mother I is crying for a murdered child [...] I| and if George Stevens hadn't been first to use I the first sixteen millimetre colour film I at Auschwitz and Ravensbrück I there's no doubt that I Elizabeth Taylor's air of wellbeing I would never have found a place in the sun". 
Beverley Ray, Robert (2001): How a Film Theory Got Lost and Other Mysteries in Cultural Studies, Indiana University Press.

Brenez, Nicole, et al. (ed.) (2001): Jeune, dure et pure !: une histoire du cinéma d'avant-garde et expérimental en France. Paris: Cinémathèque française/Mazzotta.

Brenez, Nicole, et al. (ed.) (2006): Jean-Luc Godard Documents. Paris: Editions du Centre Pompidou.

Carroll, Kent E. (1970): "Film and Revolution: Interview with the DzigaVertov Group." In: Evergreen Review 14, n. 83. Now in Royal S. Brown, Englewood Cliffs. N.J. 1972, pp. 50-64.

Burgat, Jean-Louis: 7 SUR 7, ORTF1, 11 December 1983.

Cott, Jonathan (1980): Jonathan Cott, “Godard: Born-Again Filmmaker". In: Rolling Stone, 27 nov 1980; now in David Sterritt (ed.) 1998: JeanLuc Godard: Interviews, Jackson: University of Mississippi Press, pp. 91-106.

Dauman, Anatole (1989): Argos Film. Souvenir-écran. Paris: Centre Georges Pompidou.

Deleuze, Gilles (1985): Cinéma 2. L’image-temps. Paris: Les Editions de Minuit.

Dieckmann, Katherine (1993): “Godard's Counter-Memory." In: Art in America 81, n. 10, pp. 65-67.

Dixon, Wheeler Winston (1997): The Films of Jean-Luc Godard. Albany: State University of New York Press.

Eco, Umberto (1967): Per una guerriglia semiologica [Speech at the "Vision '67' ICCAS Colloquium, New York], Il costume di casa: pp. 290295. Milano: Bompiani.

Fairfax, Daniel (2010): "Birth (of the Image) of a Nation: Jean-Luc Godard in Mozambique.” In: Acta Univ. Sapientiae, Film and Media Studies, n. 3: pp. 55-67.

Fleischer, Alain (2009): “Jean-Luc Godard m'a proposé de le filmer comme un peintre dans son atelier.” In: Libération Next, 28 Jan 2009; available from: http://next.liberation.fr/cinema/2009/01/28/jean-lucgodard-m-a-propose-de-le-filmer-comme-un-peintre-dans-sonatelier_653144 [June 15 2016].

Fleischer, Alain: MorCEUX DE CONVERSATIONS AVEC JEAN-LUC GODARD, France, 2009, 125', col. 
Fromanger, Gérard (YEAR): Il faut créer un Vietnam dans chaque musée du monde, in: Nicole Brenez et al. (ed.) (2006): Jean-Luc Godard Documents. Paris: Editions du Centre Pompidou, pp. 336-339.

Gilliat, Penelope (1976): "The Urgent Whisper." In: The New Yorker, 25 oct 1976: 47-58; now in David Sterritt (ed.) 1998: Jean-Luc Godard: Interviews, Jackson: University of Mississippi Press, pp. 69-84.

Giovannoli, Pietro (2013): "Clio, la demoiselle de l'enregistrement. Pour un atlas de l'oeuvre de Godard, philosophe-peintre." In: Kornelia Imesch/Alfred Messerli et al. (eds.), Mit Klios Augen. Das Bild als historische Quelle, Oberhausen: Athena: pp. 237-257.

Godard, Jean Luc (1950): "Pour un cinéma politique." In: Gazzette du cinéma, n. 3 (September). Now in Godard 1998: 72-74. Translation in Milne 1972: pp. 16-17.

Godard, Jean Luc (1958): "Un bon devoir." In: Cahiers du Cinéma, 80 (Feb 1958). Now in Godard 1998: pp. 121-22. Translation in Milne 1972: p. 69.

Godard, Jean Luc (1960): "Tournage. Le petit soldat.” In: Cahiers du cinéma, 106 (Avril). Now in Godard 1998: pp. 209-210.

Godard, Jean Luc (1962): "Interview with Jean-Luc Godard." In: Cahiers du cinéma, 138 (December). Now in Godard 1998: pp. 215-236. Translation in Milne 1972: pp. 171-196.

Godard, Jean Luc (1965): "Feu sur Les Carabiniers." In: Cahiers du cinéma, 171 (October). Now in Godard 1998: 238-241. Translation in Milne 1972: pp. 196-200.

Godard, Jean Luc (1966): "Grace à Henri Langlois" [speech at the Cinémathèque Française, 12 Jan 1966]. In: Le nouvel observateur, 61 (January), now in Godard 1998: pp. 280-283, translation in Milne 1972: pp. 234-37.

Godard, Jean Luc (1967): “On doit tous mettre dans un film.” In: L'AvantScène du Cinéma, 70 (May), now in Godard 1998: pp. 295-296, translation in Milne 1972: pp. 238-39.

Godard, Jean Luc (1967b): "Lutter sur deux frontes, interview by Jacques Bontemps, Jean-Louis Comolli, Michel Delahaye et Jean Narboni.” In: Cahiers du cinéma, 194 (October 1967), now in Godard 1998: pp. 303327, translation in Milne 1972: p. 69.

Godard, Jean Luc (1968): Godard, Kino-Praxis, 0 (1968). Edited by Jack Frost. 
Godard, Jean Luc (1969): Jean-Luc Godard, Cinéthique, 5 (SeptemberOctober).

Godard, Jean Luc (1970): Marcel Martin (ed.), "Interview with the Dziga Vertov Group.” In: Cinéma 70, 151 (December). Now in Godard 1998: pp. 342-350.

Godard, Jean Luc (1972): “Enquête sur une image.” In: Tel Quel, 52 (winter 1972), now in Godard 1998: pp. 350-362

Godard, Jean Luc (1975): “Godard, Télévision - cinéma - video - images paroles ....” In: Téléciné, 202 (September-October): 11.

Godard, Jean Luc (1980): Introduction à une véritable histoire du cinéma. Paris: Albatros.

Godard, Jean Luc (1992): Jean-Luc Godard in Conversation with Colin MacCabe, Appendix in Duncan Petrie (ed.), Screening Europe: Image and Identity in Contemporary European Cinema. London: BFI: pp. 97105.

Godard, Jean Luc (1994) "Histoires du cinema." In: Le Monde, 15 December 1994.

Godard, Jean Luc (1996): JLG/JLG: Phrases. Paris: P.O.L.

Godard, Jean Luc (1998): Bergala, Alain (ed.), Jean-Luc Godard par JeanLuc Godard. Paris: Ed. de l'étoile, 1985. New edition in Jean-Luc Godard par Jean-Luc Godard, vol. I, 1950-1984. Paris: Cahiers du Cinéma.

Godard, Jean Luc (1999): Histoire(s) du cinéma. Munich: ECM New Series. 4 books and a 5-cd set. French-German-English Transcription of Godard's speech for each episode.

Guillas, Jérôme (2009): “On a marché sur la Lune?” In: Le Journal du Dimanche, 17 July, available from: http://www.lejdd.fr/Societe/Sciences/ Actualite/On-a-marche-sur-la-Lune-15856 [June 15 2016].

Hansen-Løve, Igor (2014): “Opération Lune, un documentaire de William Karel." In: L'Express, 7 October 2010, available from: http://www. lexpress.fr/culture/tele/operation-lune-ce-jeudi-sur-arte_925669.html [June 15 2016].

Hori, Junji (2004): "La Géo-politique de l'image dans les HISTOIRE(s) DU CINÉMA de Jean-Luc Godard.” In: European Studies, 3: pp. 43-61.

Karel, William (2003): Opération Lune, Press Interview, Arte, 2003, available from: http://www.attitudes.ch/expos/truffes/operation \%20lune.pdf [June 15 2016]. 
Knapp, Hubert: CinÉASTES DE NOTRE TEMPS: JEAN-LuC GODARD OU LE CINÉMA AU DEFI, France, 1965, 67’, b/w.

Koller, Robert Phillip (1973): "Angle and Reality: Godard and Gorin in America." In: Sight and Sound, vol. 42, n. 3: pp. 130-133; now in David Sterritt (ed.) 1998: Jean-Luc Godard: Interviews, Jackson: University of Mississippi Press, pp. 59-68.

Leutrat, Jean-Luis/ Liandrat-Guigues, Suzanne (2005): Godard simple comme bonjour, Paris: L'Harmattan.

Loshitzky, Yosefa (1995): The Radical Faces of Godard and Bertolucci, Detroit, Michigan: Wayne State University Press.

MacCabe, Colin (1992): "Appendix 1: Jean-Luc Godard in conversation with Colin MacCabe." In: Duncan Petrie (ed.), Screening Europe: image and identity in contemporary European cinema. London : BFI Pub 1992, pp. 97-105.

McLuhan, Marshall (1995 [1964]): Understanding Media: The Extensions of Man, Cambridge, MA/ London: The MIT Press.

Milne, Tom/ Narboni, Jean (eds.) (1972): Godard on Godard: critical writings by Jean-Luc Godard, London: Secker \& Warburg.

Pivot, Bernard: BouIllon de Culture, ANTENNE 2, 10 Sept 1993.

Regard, Sylvain (1966): "La Vie moderne." In: Le Nouvel Observateur, 100 (Oct. 12-18), p. 20. Translation in Julia Lesage (1983): "Godard and Gorin's left politics, 1967-1972." In: Jump Cut, no. 28, April, pp. 51-58.

Royer, Michel: GodARD À LA TÉLÉ (1999), France, col, 53’ min.

Sacotte, Marcel (1959): La prostitution, Paris: Buchet Chastel.

Sadoul, George (1975): Dictionnaire des films, Paris: Seuil.

Sahlhab, Ghassan: Breve ReNCONTRE AVEC JEAN-LuC GodARD OU LE CINÉMA COMME MÉTAPHORE, France/Liban, 2005, 40 min, col.

Sarris, Andrew (1970): "Godard and the Revolution." In: Village Voice, April 30: 53, 61, pp. 63-64; now in David Sterritt (ed.) 1998: Jean-Luc Godard: Interviews, Jackson: University of Mississippi Press: pp. 5058.

Savignac, Jean-Paul: CHRONIQUES DE FRANCE, ORTF, March 1967.

Smith, Gavin (1996): "Jean-Luc Godard." In: Film Comment, March-April: 31-32, pp. 35-41, now in David Sterritt (ed.) 1998: Jean-Luc Godard: Interviews, Jackson: University of Mississippi Press, pp. 179-193. 
Sterritt, David (ed.) 1998: Jean-Luc Godard: Interviews, Jackson: University of Mississippi Press.

Tse-Tung, Mao (1942): Talks at the Yenan Forum on Literature and Art (May), Quotations from Chairman Mao Tse-Tung. Peking, Foreign Language Press: 1966, p. 302.

Vimenet, Catherine (1966): "Les étoiles filantes.” In: Le Nouvel Observateur, 23 March, p. 18-19.

Witt, Michael (2013): Jean-Luc Godard, Cinema Historian, Bloomington: Indiana University Press.

Youngblood, Gene (1968): "Jean-Luc Godard: No difference between Life and Cinema", Part I, Los Angeles Free Press, March 8, 1968: 15, 20; now in Sterritt 1998: 11. 
